\title{
Pendidikan Karakter Siswa Berbasis Agama di SMP Walisongo Pecangaan Jepara
}

\author{
Subaidi \\ Universitas Islam Nahdlatul Ulama Jepara \\ Email:Subaidi@unisnu.ac.id
}

Abstract. This research explains about students' character education based on religion at junior high school of walisongo pecangaan jepara in central java. The research used descriptive qualitative approach. The purpose of the research was to know an event at junior high school of walisongo pecangaan jepara in central java in the context of students' character education based on religion. The collection of the data is through observation, interview and documentation. The data analysis used non statistics data. Our research findings: first, all student commit Islamic character values such as; istighosah-mujahadah, the dhuha and dzuhur prayer together; second, environmental care value, it means that, the students always try to prevent the damage of the natural environment surround them in every single act and deed, and develop their efforts to fix environmental damage happens; third, tawadhu value, it means, the students show their humility to something exalted; fourth, mutual respect value, it means, a character of respecting parents which is implemented by caring and giving them attention, obeying their instruction, not hurting in speech, being obedient, and showing politeness to them; fifth, discipline value, it means, the students' acts indicate that their behaviors orderly and adherent to various provisions and regulations in their surroundings; sixth, honesty value, all students try to make themself as a man who can be trusted in commiting the rules; seventh, social responsible value, it means, the students always want to provide charity and assistance to the poor and other people; eighth, nationality spirit value, it means, the way of they think, act and have insight always put the national and the state interests above personal interest.

Keyword. Character education; Students; Religion; Walisongo junior high school

Abstrak. Penelitian ini menjelaskan tentang pendidikan karakter siswa berbasis agama di SMP Walisongo Pecangaan Jepara. Penelitian menggunakan pendekatan kualitatif dengan jenis penelitian deskriptif. Tujuan penelitian untuk mengetahui suatu kejadian di SMP Walisongo Pecangaan Jepara dalam konteks pendidikan karakter siswa berbasis agama. Pengumpulan data melalui observasi, wawancara dan dokumentasi. Analisis data menggunakan data non statistik. Temuan penelitian: pertama, nilai religius, yaitu seluruh siswa menjalankan nilai-nilai karakter berbasis agama seperti; istighoasahmujahadah, shalat dhuha dan berdoa, shalat dhuhur berjamaah; kedua, nilai peduli lingkungan, artinya, siswa dalam bersikap dan bertindak selalu berupaya mencegah kerusakan lingkungan alam di sekitarnya, dan mengembangkan upaya-upaya untuk memperbaiki alam yang sudah terjadi kerusakan; ketiga, nilai tawadhu', artinya, siswa menampakan kerendahan hatinya kepada sesuatu yang diagungkan; keempat, nilai hormat menghormati, artinya, sikap hormat kepada orang tua diwujudkan dengan memberikan perhatian dan kasih sayang, taat dan patuh ketika diperintah, menjaga lisan dalam pembicaraan, tidak membantah, dan menunjukkan sikap sopan ketika ada dihadapannya; kelima, nilai disiplin, artinya, tindakan siswa menunjukkan perilaku tertib dan patuh terhadap berbagai ketentuan dan peraturan yang berlaku di lingkungan sekitar; keenam, nilai jujur, seluruh siswa berupaya menjadikan dirinya sebagai orang yang bisa dipercaya dalam menjalankan semua peraturan yang telah ditetapkan; ketujuh,

Vol. 4 No. 1, Juni 2019

J-MPI homepage: http://ejournal.uin-malang.ac.id/index.php/jmpi/index 
nilai peduli sosial, artinya, siswa bersikap dan bertindak yang selalu ingin memberi bantuan pada orang lain dan masyarakat yang membutuhkan; kedelapan, nilai semangat kebangsaan, artinya, cara berpikir, bertindak dan berwawasan yang menempatkan kepentingan bangsa dan negara diatas kepentingan diri dan kelompoknya).

Kata Kunci. Pendidikan karakter; Siswa; Agama; SMP Walisongo

Copyright ( JMPI: Jurnal Manajemen Pendidikan Islam. All Right Reserved.

This is an open access article under the CC BY-NC-ND license

(http://creativecommons.org/licenses/by-nc-nd/4.0/).

\section{A. PENDAHULUAN}

Permasalahan terbesar bangsa Indonesia saat ini adalah adanya ancaman penurunan nilai karakter ditengah kehidupan masyarakat, sebagai akibat dari terjadinya perubahan lingkungan global yang melanda hampir seluruh bangsa di dunia. Kegelisahan masyarakat terhadap perubahan tersebut, tentu menuntut perlunya berbagai strategi tepat guna untuk menyiapkan sumber daya manusia berkualitas dalam menjaga jati diri dalam suatu bangsa. Dalam konteks ini, Indonesia telah menempatkan sektor pendidikan sebagai sektor yang sangat penting (Hasan dan Firdaos, 2017: 268).

Melihat pentingnya pendidikan tersebut diatas, keberadaan pendidikan pada setiap jenjang termasuk SMP Walisongo Pecangaan Jepara perlu diupayakan dalam rangka mencetak generasi muda yang berkarakter mulia. Pendidikan karakter siswa berbasis agama harus diselenggarakan secara terstruktur dan kolaboratif guna mencapai tujuan yaitu pembentukan karakter siswa yang bermoral, beretika, sopan santun ketika berinteraksi dengan sesama manusia.

Kementerian Pendidikan Nasional juga telah mengembangkan grand design pendidikan karakter di setiap jalur, jenjang, dan jenis satuan pendidikan. Grand design menjadi sumber rujukan konseptual dan operasional pengembangan, pelaksanaan, dan penilaian pendidikan karakter. Sebagai tindak lanjut kebijakan tersebut, pemerintah telah merumuskan lima nilai utama karakter yang saling berhubungan membentuk jejaring nilai serta perlu dikembangkan sebagai prioritas gerakan PPK. Kelima nilai utama karakter bangsa tersebut adalah; (1) religius, (2) nasionalis, (3) mandiri, (4) gotong royong, dan (5) integritas (Hasan dan Firdaos, 2017: 268-269).

Istilah karakter sendiri banyak pemaknaan oleh berbagai ahli: sebagai tabiat, perangai, dan sifat-sifat orang. Karakter terbentuk melalui interaksi yang penuh muatan perasaan dan kedekatan dengan anak-anak sehingga nilai-nilai moral dapat dicapai dan dihayati dan selanjutnya menjadi bagian dari sikap dirinya yang dilakukan dalam tindakan kehidupan. Mencermati kajian tersebut, perlu kiranya dibutuhkan analisis mendalam tentang pendidikan karakter siswa berbasis agama di SMP Walisongo Pecangaan Jepara. Kegiatan keagamaan tersebut meliputi: shalat berjama'ah, membaca wirid sesudah shalat maktubah, istighasah, pembiasaan tahlil, shalat dhuha, membaca do'a belajar, berdoa akhir belajar, cinta lingkungan, cinta tanah air, disiplin, dan bertanggung jawab.

Dalam menyusun penelitian ini, penulis juga mengambil beberapa referensi sebagai acuan. Pertama adalah jurnal yang ditulis M. Syaifuddien Zuhriy, bertema Budaya Pesantren dan Pendidikan Karakter pada Pondok Pesantren Salaf. Dalam penelitian ini peneliti berkesimpulan bahwa pembentukan karakter yang dikembangkan

Vol. 4 No. 1, Juni 2019

J-MPI homepage: http://ejournal.uin-malang.ac.id/index.php/jmpi/index 
di pesantren ini antara lain; peningkatan budaya disiplin, budaya mandiri, budaya bersih dan peduli lingkungan (Zuhriy, 2011: 307).

Kedua adalah jurnal dari Sutoyo, bertema Pendidikan Moral Berbasis Pada Karakteristik Siswa dan Budaya. Penelitian ini berkesimpulan bahwa seluruh pimpinan sekolah, guru, tenaga kependidikan, dan siswa melaksanakan program pembentukan moral atau karakter dalam kehidupan sehar-hari di sekolah maupun luar sekolah (Sutoyo, 2011: 86).

Yang ketiga adalah jurnal yang ditulis Muhammad Yusuf, bertema Pendidikan Karakter Berbasis Qurani dan Kearifan Lokal. Penelitian ini berkesimpulan bahwa pendidikan sejatinya mampu membentuk karakter melalui penanaman nilai-nilai agama dan kearifan lokal. Pertama, pengawasan melekat dengan pendekatan agama yaitu pemberdayaan nilai-nilai agama dalam rangka pencegahan dini terhadap korupsi dan manipulasi. Kedua, pemberdayaan nilai-nilai kearifan lokal, dalam konteks inibudaya Bugis yang relevan dengan ajaran Islam.Kearifan budaya dan ajaran Islam mengajarkan kebenaran universal berupa kejujuran dan integritas serta nilai-nilai kebenaran dan kebaikan lainnya (Yusuf, 2014: 53).

Terakhir jurnal bertema "Peran SMP Berbasis Pesantren sebagai Upaya penanaman Pendidikan Karakter kepada Generasi Muda" yang ditulis oleh Didik Suhardi (Direktur Pembinaan SMP Ditjen Dikdas Kemdikbud). Akhir dari penelitian menyimpulkan bahwa salah satu upaya yang dilakukan pemerintah bersama sama dengan lembagai pendidikan serta masyarakat untuk membentuk karakter generasi muda adalah melalui program sekolah menengah berbasis pondok pesantren. Model seperti ini memiliki keunggulan dua system dalam membentuk peserta didik yang berkarakter mulia.

Bedasarkan telaah penelitian terdahulu ini dapat diketahui bahwa sebenarnya penelitian tentang pendidikan karakter siswa berbasis agama sudah banyak dilakukan, namun analisisnya belum pernah dilakukan untuk mengkaji budaya agama dilingkungan SMP Walisongo Pecangaan Jepara. Beberapa kajian yang ada juga belum spesifik menganalisis pendidikan karakter siswa berbasis agama. Oleh karena itu, penelitian ini merupakan penemuan baru dalam memperluas kajian pendidikan karakter siswa berbasis agama di SMP Walisongo Pecangaan Jepara.

Tujuan dalam penelitian ini adalah untuk mengetahui pendidikan karakter siswa berbasis agama dan mengetahui nilai-nilai karakter siswa berbasis karakter bangsa. Penelitian ini dilaksanakan di SMP Walisongo Pecangaan Jepara. Sekolah ini dipilih karena lembaga ini merupakan sekolah menengah pertama swasta yang memiliki pengaruh besar di kecamatan Pecangaan, Kabupaten Jepara. Untuk batasan penelitian hanya pada permasalahan mengenahi: a) upaya sekolah dalam mewujudkan pendidikan karakter berbasis agama, b) upaya sekolah dalam mewujudkan nilai-nilai karakter siswa berbasis karakter bangsa dilingkungan SMP Walisongo Pecangaan Jepara.

\section{B. METODE}

Penelitian ini menggunakan pendekatan kualitatif dengan jenis penelitian deskriptif. Pendekatan kualitatif yaitu penelitian yang menggunakan pengumpulan data/informasi sebanyak-banyaknya mengenai gejala yang ada di tempat penelitian. Deskriptif berisikan gambaran tentang latar pengamatan orang, tindakan dan pembicaraan (Moleong, 2004: 3).

Vol. 4 No. 1, Juni 2019

J-MPI homepage: http://ejournal.uin-malang.ac.id/index.php/jmpi/index 
Tempat penelitian adalah di SMP Walisongo Pecangaan Jepara. Subyek dalam penelitian ini adalah guru dan siswa-siswa SMP Walisongo Pecangaan Jepara, sedang yang menjadi informannya adalah kepala sekolah, waka kesiswaan, guru dan orang tua siswa. Metode pengumpulan data melalui observasi, wawancara dan dokumentasi. Data observasi diperoleh dengan mengamati kegiatan pembiasaan siswa terkait dengan istighoasah-mujahadah, shalat dhuha dan berdoa, shalat dzuhur berjamaah dilingkungan SMP Walisongo. Demikian pula data diperoleh melalui wawancara dengan pengurus yayasan bidang pendidikan, guru, karyawan dan siswa, sedangkan dokumentasi terkait dengan jadwal kegiatan pendidikan karakter siswa berbasis agama diperoleh dari dokumen-dokumen sekolah dari wakil kepala sekolah dan staf tata usaha. Analisis data penelitian menggunakan analisis deskriptif. Prosesnya dilakukan semenjak pengumpulan data, sehingga saat dilapangan, peneliti sudah mulai melakukan proses analisis data hingga penelitian berakhir. Sugiyono menjelaskan bahwa analisis data dalam penelitian kualitatif hendaknya dilakukan secara interaktif dan terus menerus hingga tuntas sehingga datanya menjadi jenuh. Adapaun langkah-langkah analisis data meliputi reduksi data, penyajian data, dan diakhiri dengan penarikan kesimpulan dan verifikasi (Sugiyono, 2008: 246).

\section{HASIL DAN PEMBAHASAN}

\section{Nilai-Nilai Pendidikan Karakter}

Secara etimologis, karakter adalah tabiat atau kebiasaan. Sedangkan menurut ahli psikologi, karakter adalah sebuah sistem keyakinan dan kebiasaan yang mengarahkan tindakan seorang individu. Karena itu, jika pengetahuan mengenai karakter seseorang itu dapat diketahui, maka dapat diketahui pula bagaimana individu tersebut akan bersikap untuk kondisi-kondisi tertentu. Dari sudut pengertian berarti karakter dan akhlak tidak memiliki perbedaan yang signifikan. Keduanya didefinisikan sebagai suatu tindakan yang terjadi tanpa ada lagi pemikiran lagi karena sudah tertanam dalam pikiran, dan dengan kata lain keduanya dapat disebut dengan kebiasaan (Sri Haryati, 2017: 4).

Pendidikan karakter menurut Siswanto (2013: 97) merupakan ikhtiyar mengembangkan potensi siswa dengan nilai-nilai budaya dan karakter bangsa agar mereka memiliki nilai dan karakter sebagai karakter dirinya, mengimplementasikan nilai-nilai tersebut dalam kehidupan dirinya, sebagai anggota masyarakat, dan sebagai warga negara. Sedangkan menurut Thomas Lickona pendidikan karakter adalah pendidikan dimana tujuannya untuk membentuk kepribadian seseorang melalui pendidikan, yang hasilnya terlihat dalam tindakan riil seseorang, yaitu tingkah laku yang baik dan jujur, bertanggung jawab, menghormati hak orang lain, kerja keras, dan sebagainya.

Terkait pemikiran diatas, sebagai landasan pendidikan dan pembinaan karakter bangsa yang telah dikembangkan di SMP Walisongo Pecangaan Jepara adalah digali dari nilai-nilai yang selama ini menjadi karakter bangsa Indonesia, salah satunya ialah nilainilai agama, Pancasila, budaya bangsa. Nilai agama, artinya masyarakat Indonesia adalah masyarakat beragama. Oleh karena itu, kehidupan individu, masyarakat, dan bangsa selalu didasari pada ajaran agama dan kepercayaan. Secara politis, kehidupan kenegaraan pun didasari pada nilai-nilai yang berasal dari agama. Atas dasar

Vol. 4 No. 1, Juni 2019

J-MPI homepage: http://ejournal.uin-malang.ac.id/index.php/jmpi/index 
pertimbangan itu, maka nilai-nilai pendidikan karakter harus didasarkan pada nilai-nilai dan kaidah yang berasal dari agama (Kosim, 2011: 88).

Terdapat delapan belas nilai-nilai dalam pendidikan karakter menurut Diknas adalah: pertama, religius, yaitu sikap dan perilaku yang patuh dalam melaksanakan ajaran agama yang dianutnya, toleran terhadap pelaksanaan ibadah agama lain, dan hidup rukun dengan pemeluk agama lain; kedua, jujur, artinya perilaku yang didasarkan pada upaya menjadikan dirinya sebagai orang yang selalu dapat dipercaya dalam perkataan, tindakan, dan pekerjaan; ketiga, toleransi, sikap dan tindakan yang menghargai perbedaan agama, suku, etnis, pendapat, sikap, dan tindakan orang lain yang berbeda dari dirinya; keempat, tindakan yang menunjukkan perilaku tertib dan patuh pada berbagai ketentuan dan peraturan yang berlaku; kelima, kerja keras, artinya perilaku yang menunjukan upaya sungguh- sungguh dalam mengatasi berbagai hambatan belajar dan tugas, serta menyelesaikan tugas dengan sebaik-baiknya; keenam, kreatif, yaitu berpikir dan melakukan sesuatu untuk menghasilkan cara atau hasil baru dari sesuatu yang telah dimiliki; ketujuh, mandiri, yaitu sikap dan perilaku yang tidak mudah tergantung pada orang lain dalam menyelesaikan tugas-tugas; kedelapan, demokratis, artinya, cara berfikir, bersikap, dan bertindak yang menilai sama hak dan kewajiban dirinya dan orang lain; kesembilan, rasa ingin tahu, yaitu sikap dan tindakan yang selalu berupaya untuk mengetahui lebih mendalam dan meluas dari sesuatu yang dipelajarinya, dilihat, dan didengar; kesepuluh, semangat kebangsaan, yaitu cara berpikir, bertindak, dan berwawasan yang menempatkan kepentingan bangsa dan negara di atas kepentingan diri dan kelompoknya; kesebelas, cinta tanah air, yaitu cara berpikir, bertindak, dan berwawasan yang menempatkan kepentingan bangsa dan negara di atas kepentingan diri dan kelompoknya; keduabelas, menghargai prestasi, yaitu sikap dan tindakan yang mendorong dirinya untuk menghasilkan sesuatu yang berguna bagi masyarakat, dan mengakui, serta menghormati keberhasilan orang lain; ketigabelas, bersahabat/ komunikatif, yaitu sikap dan tindakan yang mendorong dirinya untuk menghasilkan sesuatu yang berguna bagi masyarakat, dan mengakui, serta menghormati keberhasilan orang lain; keempatbelas, cinta damai, yaitu sikap dan tindakan yang mendorong dirinya untuk menghasilkan sesuatu yang berguna bagi masyarakat, dan mengakui, serta menghormati keberhasilan orang lain; kelimabelas, gemar membaca, yaitu kebiasaan menyediakan waktu untuk membaca berbagai bacaan yang memberikan kebajikan bagi dirinya; keenambelas, peduli lingkungan, yaitu sikap dan tindakan yang selalu berupaya mencegah kerusakan pada lingkungan alam di sekitarnya, dan mengembangkan upaya-upaya untuk memperbaiki kerusakan alam yang sudah terjadi; ketujuhbelas, peduli sosial, yaitu sikap dan tindakan yang selalu ingin memberi bantuan pada orang lain dan masyarakat yang membutuhkan; kedelapanbelas, tanggung jawab, yaitu sikap dan perilaku seseorang untuk melaksanakan tugas dan kewajibannya, yang seharusnya dia lakukan, terhadap diri sendiri, masyarakat, lingkungan (alam, sosial dan budaya), negara dan Tuhan Yang Maha Esa (Kosim, 2011: 89).

\section{Pendidikan Karakter Siswa di SMP Walisongo}

Untuk mempersiapkan sumber daya manusia Indonesia yang berkualitas, peranan pendidikan sangat menentukan dalam mempersiapkan dan membentuk generasi muda dimasa mendatang. Dimana pendidiakn adalah proses belajar yaitu 
proses kegiatan untuk mengarahkan pola tingkah laku siswa dari tidak baik menjadi baik, sehingga akan dihasilkan siswa yang berperilaku baik (Sumarlika, 2015: 136). Untuk mempersiapkan sumberdaya manusia tersebut SMP Walisongo Pecangaan Jepara melakukan pendidikan karakter siswa-siswinya berbasis agama. Hal ini sejalan dengan visi-misi SMP Walisongo Pecangaan Jepara. Bahwa lembaga tersebut telah melaksanakan dan mengimplementasikan pendidikan karakter berbasis agama secara rutin. Sebagaimana diungkapakan pengurus yayasan Walisongo Pecangaan Jepara bidang pendidikan Muh Nasuka: "pendidikan yang sesungguhnya seharusnya menyentuh tiga aspek yaitu kognitif, afektif, dan psikomotorik". SMP ini merupakan salah satu unit lembaga di Walisongo yang memasukkan nilai-nilai pendidikan karakter berbasis agama terimplementasi pada semua kegiatan termasuk kegiatan ekstrakurikuler (Wawancara tanggal 3 April 2017).

Dewan guru, karyawan dan siswa di SMP Walisongo Pecangaan Jepara dalam mengimplementasikan pendidikan karakter bukan sesuatu yang asing, karena pada dasarnya setiap even kegiatan apapun mereka dituntut untuk merealisasikan bentukbentuk pendidikan karakter secara lebih rinci, diuraikan sebagai berikut:

1) Nilai religius. Artinya sikap dan perilaku yang patuh dalam melaksnakan ajaran agama yang dianutnya, toleran terhadap pelaksanaan ibadah agama lain, dan selalu hidup rukun dengan pemeluk agama lain. Dalam konteks ini, menurut Moh Nasuka: "siswa SMP Walisongo Pecangaan Jepara setiap seminggu sekali melaksanakan ajaran agama yaitu berdoa melalui cara istighosah-mujahadah". Kegiatan ini dilakukan dengan harapan agar selama mencari ilmu diberi kemudahan dan kelancaran oleh Allah yang akhirnya ilmu yang diterima bermanfaat (Wawancara tanggal 13 April 2017).

Disamping pendidikan karakter siswa dengan cara istighosah-mujahadah, dari hasil observasi dan dokumen jadwal yang diperoleh peneliti, sekolah juga memprogramkan shalat dhuha pada jam istirahat pertama yang diikuti seluruh siswa, dan dilanjutkan membaca tahlil sebagaimana struktur bacaan tahlil yang berlaku. Kegiatan pendidikan tersebut dipusatkan di masjid Walisongo Pecangaan Jepara. Sebagai imam shalat dhuha dan pimpinan bacaan tahlil ditunjuklah salah satu siswa yang telah bergabung dalam kegiatan tersebut. Pendidikan karakter siswa berikutnya adalah melantunkan doa setiap awal pembelajaran dan akhir pembelajaran. Pembiasaan shalat dhuha dan membaca tahlil dilakukan secara serenatak sebelum jam efektif kegiatan pembelajaran dengan durasi waktu 05-10 menit dengan bimbingan guru hari Sabtu: Nurul Zulaikhah, Ahad: Isna, Senin: Mulyono, Selasa: Ulin Nuha, Rabo: Ridlwan, dan Kamis: Fathul Amin (Dokumen Sekolah, 13 April 2017).

Pembiasan berdoa melalui istighasah dan mujahadah, shalat dhuha, membaca tahlil tersebut sejalan dengan konsep yang dinyatakan oleh Kosim (2011: 89) bahwa salah satu dari delapan belas pilar karakter bangsa adalah nilai relegius, yaitu sikap dan perilaku yang patuh dalam melaksnakan ajaran agama yang dianutnya. Begitu pula menurut Asmani (2011), bahwa jenis karakter yang diterapkan dalam proses pendidikan ada empat, salah satunya ialah pendidikan karakter berbasis nilai religius; artinya siswa dilingkungan SMP Walisongo pecangaan Jepara telah membiasakan perilaku keagamaan seperti doa ketika awal dan akhir pembelajaran, istighasah dan mujahadah, shalat dhuha, dan membaca tahlil yang dilakukan secara riil dalam aktifitas sehari-hari.

Vol. 4 No. 1, Juni 2019

J-MPI homepage: http://ejournal.uin-malang.ac.id/index.php/jmpi/index 
2) Nilai Peduli Lingkungan. Peduli lingkungan adalah sikap dan tindakan yang selalu berupaya mencegah kerusakan lingkungan alam di sekitarnya, dan mengembangkan upaya-upaya untuk memperbaiki alam yang sudah terjadi kerusakan. Sebagaimana pernyataan Moh Nasuka: "siswa dilingkungan SMP Walisongo memiliki tanggung jawab terhadap lingkungan sosial, khususnya dalam lingkungan pendidikan". Siswa dalam proses pembelajaran harus bersungguh-sungguh, tidak banyak bersenda gurau, menjaga kondusifitas lingkungan belajar ketika menerima pelajaran. Dalam pergaulan di sekolah, siswa SMP Walisongo tidak bertengkar dengan teman, saling menjaga hubungan pertemanan mereka. Karena sekolah merupakan salah satu ujung tombak untuk mencapai fungsi membentuk manusia yang peduli lingkungan. Sekolah merupakan wadah yang tepat untuk membangun karakter siswa terkait dengan peduli lingkungan. Oleh karenanya sekolah harus mampu memberikan pengalaman belajar kepada siswa dan memberikan motivasi positif agar kelestarian lingkungan hidup tetap terjaga.

Pengembangan pendidikan karakter siswa peduli lingkungan berikutnya adalah siswa SMP Walisongo diwajibkan "membuang sampah pada tempatnya", artinya tidak diperkenankan membuang sampah-sampah disembarang tempat. Salah satu upaya sekolah menyediakan tong-tong sampah di berbagai titik dan sudut sekolah, agara siswa lebih mudah dan nyaman ketika akan membuang sampah (Wawancara tanggal 17 Maret 2017). Larangan membuang sampah disembarang tempat tertuang dalam tata tertib sekolah menengah pertama Walisongo Pecangaan Jepara pasal 5 bab II terkait dengan Kebersihan (Dok, 17 Maret 2017). Hal demikian sejalan dengan pernyataan Thomas Lickona yang dikutip Ainissyifa bahwa tujuan pendidikan karakter adalah membentuk kepribadian seseorang melalui pendidikan, yang hasilnya terlihat dalam tindakan riil, dalam konteks ini adalah tingkah laku yang baik dan jujur, bertanggung jawab, menghormati hak orang lain, kerja keras, dan sebagainya (Ainissyifa, 2014: 5).

Di lingkungan SMP Walisongo Pecangaan Jepara peran guru sangat dominan dan perilaku kepedulian guru terkait menjaga lingkungan menjadi ukuran keteladanan siswa siswinya dalam mewujudkan tingkah laku baik. Kegiatan peduli lingkungan yang bisa diwujudkan oleh guru kepada siswa adalah: 1) membuang sampah yang baik; 2) menyiram tanaman dengan hemat air; 3) penggunaan plastik kiloan, dan 4) Menanam pohon atau tanaman di sekitar rumah atau sekolah. Keberhasilan dewan pengasuh/ guru menjadi teladan didasarkan pada ikhiyar-ikhtiyar untuk menjadikan budaya positif yang dilakukan guru sebagai usaha menjaga kelestarian lingkungan (Andriana Marsianti, 2014: 4).

3) Nilai tawadhu'. Tawadhu' adalah menampakan kerendahan hati kepada sesuatu yang diagungkan. Bahkan, ada juga yang mengartikan tawadhu' sebagai tindakan berupa mengagungkan orang karena keutamaannya, menerima kebenaran dan seterusnya (Rusdi, 2013: 15). Dalam lingkungan sosial, menurut Nurul Zulaikhah bahwa siswa SMP Walisongo juga harus bersopan-satun dan mengedapankan sikap tawadhu'. Dalam aktivitas dan pergaulan ehari-hari siswa tidak boleh sombong dengan memamerkan kekayaan atau jabatan yang dimiliki orang tua mereka. Seorang anak harus pandai menempatkan diri dengan lingkungannya (Wawancara tanggal 27 April 2017). Hasil pengamatan menyimpulkan bahwa siswa SMP ketika ada guru masuk kelas pada saat sebelum proses pembelajaran semua siswa di kelas tersebut langsung melakukan bersalaman dengan guru tersebut dengan cara membungkukkan badan, 
itulah sikap $t a^{\prime} d z i m$ kepada guru, hemat peneliti tindakan tersebut merupakan pembiasaan karakter tawadhu' yang dimiliki oleh seluruh siswa. Nilai tawadhu' ini juga tertuang dalam tata tertib sekolah menengah pertama Walisongo Pecangaan Jepara pasal 2 bab III terkait dengan Kedisiplinan sekolah (Dok, 17 Maret 2017).

Tanda-tanda orang yang tawadhu' kepada sesama manusia antara lain; menerima nasehat/saran kebenaran dari orang lain; senantiasa melihat kelebihan-kelebihan saudaranya, dan berusaha menutupi kekurangan- kekurangannya; siap membantu orang lain; bermusyawarah dengan anggota masyarakat yang lain; senantiasa berbaik sangka (khusnudzon) kepada orang lain (Purnama Rozak, 2017: 186).

4) Nilai hormat menghormati. Sikap hormat ini menurut Irbab pertama sekali ditanamkan kepada siswa dilingkungan SMP Walisongo Pecangaan Jepara adalah hormat kepada orang tua. Sikap hormat kepada orang tua diwujudkan dengan memberikan perhatian dan kasih sayang, taat dan patuh ketika diperintah, menjaga lisan dalam pembicaraan, tidak membantah, dan menunjukkan sikap sopan ketika ada dihadapannya. Hormat kepada pengasuh atau guru, baik disekolah maupun diluar sekolah. Sikap $t a^{\prime} d z i m$ kepada guru ini akan mendatangkan berkah ilmu manfaat (wawancara tanggal 2 Maret 2017).

Hasil pengamatan menyimpulkan bahwa siswa SMP ketika berpapasan dengan guru dan tenaga kependidikan lainnya di sekolah menengah pertama Walisongo secara reflex memberi hormat dengan bersalaman dan mengucapkan assalamu'alaikum kepada guru dan tenaga kependidikan yang lain, hal demikian menunjukkan sikap $t a^{\prime} d z i m$ kepada guru, yang pada akhirnya akan bisa berlanjut hormat kepada orang tua, dan orang-orang dilingkungan masyarakat. Hal demikian hemat peneliti tindakan tersebut merupakan pembiasaan karakter hormat menghormati yang dilakukan oleh seluruh siswa dilingkungan sekolah. Karakter hormat menghormati juga tertuang dalam tata tertib sekolah menengah pertama Walisongo Pecangaan Jepara pasal 2 bab III terkait dengan Kedisiplinan sekolah (Dok, 17 Maret 2017).

Sikap hormat kepada orang tua, kepada pengasuh atau guru, baik di sekolah maupun diluar sekolah tersebut, sejalan dengan apa yang dinyatakan oleh Thomas Lickona, dalam Ainissyifa bahwa tujuan pendidikan karakter adalah membentuk kepribadian seseorang melalui pendidikan, yang hasilnya terlihat dalam tindakan riil, dalam konteks ini adalah tingkah laku yang baik dan jujur, bertanggung jawab, menghormati hak orang lain, kerja keras, dan sebagainya (Ainissyifa, 2014: 5). Karena sekolah merupakan salah satu tempat yang strategis dalam pembentukan karakter selain keluarga dan masyarakat (Hamid, 2017: 3).

Kemudian sikap hormat terhadap orang lain merupakan langkah awal dalam membentuk perilaku tanggung jawab. Dengan sikap hormat ini akan menyadari bahwa keberadaan dirinya tidak bisa menafikan terhadap orang lain, termasuk teman sendiri. Siswa dengan sendirinya mengerti bahwa egoisme, acuh, tidak peduli sesama adalah perilaku yang kurang baik. Artinya, dengan teman bermain juga harus bersikap baik tidak boleh jahat. Ketika bermain jangan sampai bercanda yang berlebihan, seperti mengejek teman dengan kata-kata yang kurang layak. Dengan orang lain, siswa juga harus menunjukkan sikap bersahabat dan memberikan rasa hormat. Ketika dirumah, perhormatan kepada orang lain juga diwujudkan ketika orang tua sedang menerima tamu. Bentuk penghormatan pada tamu, yaitu dengan tidak mengganggu pembicaraan orang tua dengan cara menangis minta uang atau minta makanan, dan lain sebagainya.

Vol. 4 No. 1, Juni 2019

J-MPI homepage: http://ejournal.uin-malang.ac.id/index.php/jmpi/index 
5) Nilai Disiplin. Disiplin adalah tindakan yang menunjukkan perilaku tertib dan patuh terhadap berbagai ketentuan dan peraturan yang berlaku di lingkungan sekitar. SMP Walisongo Pecangaan Jepara telah meprogramkan kedisiplinan seragam berpakain dengan ketentuan hari: Sabtu dan ahad seragam pramuka, senin - selasa seragam sekolah (abu-abu putih), Rabu - Kamis seragam batik LP. Ma'arif NU. Realisasi seharihari siswa dilingkangan sekolah menegah pertama walisongo secara tertib benar-benar patuh dan taat terhadap ketentuan tersebut. Dalam memanfaatkan waktu, siswa tidak boleh terlena, karena waktu yang sudah terlanjur terbuang, tidak bisa dikembalikan. Waktu lebih baik digunakan untuk belajar dan menuntut ilmu, tidak habis hanya untuk bermain saja.

Disiplin merupakan alat untuk mendidik siswa sehingga mereka dapat beradaptasi di lingkungan sekolah, khususnya SMP Walisongo Pecangaan Jepara. Dalam konteks ini menurut Uswatun Hasanah bahwa siswa dikenalkan aturan-aturan yang berlaku, bersifat rutin dan disesuaikan dengan kondisi siswa. Guru bisa memulai pengenalan dan melakukan aturan-aturan yang terprogram di sekolah, karenanya guru sangat berperan penting sebagai pengajar dan teladan bagi siswa. Salah satu contoh disiplin di sekolah menengah walisongo Pecangaan adalah: datang tepat waktu, memakai pakaian seragam sekolah sesuai jadwal, mengerjakan PR yang ditugaskan guru, tidak membuat gaduh di kelas, izin kepada guru sebelum meninggalkan kelas, tidak membuang sampah sembarang tempat, mematuhi peraturan tata tertib sekolah (Dokumen sekolah dan wawancara tanggal 9 Februari 2017). Salah satu nilai karakter yang perlu dikembangkan adalah disiplin. Nilai karaker disiplin sangat penting dimiliki siswa agar kemudian muncul nilai-nilai karakter baik lainnya. Penguatan nilai disiplin ini dianggap peenting dengan alasan bahwa sekarang banyak terjadi perilaku menyimpang yang bertentangan dengan norma kedisiplinan (Hakim, 2017: 778).

6) Nilai Jujur. Jujur adalah perilaku yang didasarkan pada upaya menjadikan dirinya sebagai orang yang dapat dipercaya dalam perkataan, tindakan dan perbuatan. Dari rasa tanggung jawab kepada Tuhan, lahir sikap karakter religius dan jujur dalam diri siswa. Religius ini dibangun tidak semata-mata karena dorongan dari luar, tetapi lahir dari kesadaran. Buah dari rasa tanggung jawab kepada Tuhan juga akan melahirkan sikap jujur pada diri seorang siswa. Artinya, siswa SMP Walisongo akan senantiasa berkata apa adanya, dan melakukan tindakan sesuai dengan hati nurani mereka. Karena jiwa religius yang sudah terpatri pada diri seorang siswa, akan melahirkan perasaan diawasi oleh Yang Maha Kuasa yaitu Allah SWT. Tidak ada satu pun dari perbuatan siswa yang bisa lepas dari pengawasan Allah SWT. Hasil observasi menyimpulkan bahwa siswa dilingkungan sekolah bersungguh-sungguh dalam menjalankan kejujuran terkait dengan ketentuan dan aturan pembiasaan shalat dhuha, membaca tahlil, shalat jama'ah dhuhur, buang sampah pada tempat yang tersedia, gerakan infaq-shadaqah, dan dalam mengikuti upacara bendera dan peringatan hari besar nasional dan Islam.

7) Nilai Peduli Sosial. Peduli sosial adalah sikap dan tindakan yang selalu ingin memberi bantuan pada orang lain dan masyarakat yang membutuhkan. Nilai peduli sosial ini perlu diterapkan dalam kehidupan sehari-hari, karena akan menghasilkan keseimbangan antara hak dan kewajiban seorang individu dengan individu lain. Banyak nilai-nilai kebaikan yang sebaiknya ditanamkan kepada diri siswa, yakni kepedulian terhadap sesama. Seiring dengan berkembangnya waktu dan zaman, rasa kepedulian terhadap sesama mulai banyak berubah dan luntur, sehingga dengan menanamkan rasa

Vol. 4 No. 1, Juni 2019

J-MPI homepage: http://ejournal.uin-malang.ac.id/index.php/jmpi/index 
peduli terhadap sesama, maka di masa depan lingkungan siswa akan tumbuh dan tetap menjunjung tinggi rasak epedulian yang besar bagi sesama (A. Tabi'in, 2017: 42). Menurut Uswatun hasanah bahwa rasa kedisiplinan siswa tersebut diimplementasikan di SMP Walisongo Pecangaan Jepara berupa gerakan infaq dan shodaqah. Kegiatan ini dilakukan setiap hari sabtu dengan harapan siswa dibiaskan untuk melakukan infaq dan shodaqah agar terpatri dalam diri mereka karakter kepedulian sosial. Hasil dari infaqshodaqah ini dipergunakan santunan ketika ada teman sekolah yang sakit dan kena musibah (Dokumen sekolah dan wawancara tanggal 29 Maret 2017).

8) Nilai Semangat Kebangsaan. Semangat kebangsaan adalah cara berpikir, bertindak dan berwawasan yang menempatkan kepentingan bangsa dan negara diatas kepentingan diri dan kelompoknya. Nilai ini sangat menjunjung tinggi rasa cinta pada tanah air serta menempatkan kepentingan negara di atas kepentingan pribadi atau kelompok. Menanamkan karakter semangat kebangsaan kepada siswa, menurut Moh Nasuka: salah satunya adalah kegiatan rutin upacara bendera yang dilaksanakan setiap hari Senin dan upacara pada hari-hari besar nasional, seperti Hari Pendidikan dan Hari Kemerdekaan Indonesia tanggal 17 Agustus. Adapun petugas upacar bendera dilaksanakan oleh para siswa secara bergantian. Seluruh siswa harus mengikuti upacara bendera setiap hari Senin tersebut, kecuali berhalangan yang dapat dibenarkan (udzur syar'i) seperti sakit atau tidak masuk sekolah karena suatu kepentingan keluarga, dan udzur syar'i lainnya bisa mengajukan izin (Wawancara tgl 10 Agustus 2017). Kegiatan pembiaasaan upacara baik upacara bendera, upacara peringatan hari besar nasional adalah sejalan dengan pemikiran Siswanto (2013: 97) bahwa pendidikan karakter merupakan ikhtiyar mengembangkan potensi siswa dengan nilai-nilai budaya dan karakter bangsa agar mereka memiliki nilai dan karakter sebagai karakter dirinya, mengimplementasikan nilai-nilai tersebut dalam kehidupan dirinya, sebagai anggota masyarakat, dan sebagai warga Negara. Penanaman Karakter semangat kebangsaan juga tertuang dalam tata tertib sekolah menengah pertama Walisongo Pecangaan Jepara pasal 2 bab III terkait dengan Kedisiplinan sekolah, terwujud dalam kesungguhan siswa dalam mengikuti dan melaksanakan upacara bendera di sekolah (Dok, 17 Maret 2017).

\section{KESIMPULAN}

Berdasarkan hasil penelitian di SMP Walisongo Pecangaan Jepara terkait dengan pendidikan karakter siswa berbasis agama dapat diambil kesimpulan sebagai berikut: pertama, nilai religius, yaitu seluruh siswa menjalankan nilai-nilai karakter berbasis agama seperti; istighoasah-mujahadah, shalat dhuha dan berdoa, shalat dzuhur berjamaah; kedua, nilai peduli Lingkungan, artinya, siswa dalam bersikap dan bertindak selalu berupaya mencegah kerusakan lingkungan alam di sekitarnya, dan mengembangkan upaya-upaya untuk memperbaiki alam yang sudah terjadi kerusakan; ketiga, nilai tawadhu', artinya, siswa menampakan kerendahan hatinya kepada sesuatu yang diagungkan; keempat, nilai hormat menghormati, artinya, sikap hormat kepada orang tua diwujudkan dengan memberikan perhatian dan kasih sayang, taat dan patuh ketika diperintah, menjaga lisan dalam pembicaraan, tidak membantah, dan menunjukkan sikap sopan ketika ada dihadapannya; kelima, nilai disiplin, artinya, tindakan siswa menunjukkan perilaku tertib dan patuh terhadap berbagai ketentuan dan peraturan yang berlaku di lingkungan sekitar; keenam, nilai jujur, seluruh siswa berupaya menjadikan dirinya sebagai orang yang bisa diprcaya dalam menjalankan

Vol. 4 No. 1, Juni 2019

J-MPI homepage: http://ejournal.uin-malang.ac.id/index.php/jmpi/index 
semua peraturan yang telah ditetapkan; ketujuh, nilai peduli sosial, artinya, siswa bersikap dan bertindak yang selalu ingin memberi bantuan pada orang lain dan masyarakat yang membutuhkan; kedelapan, nilai semangat kebangsaan, artinya, cara berpikir, bertindak dan berwawasan yang menempatkan kepentingan bangsa dan negara diatas kepentingan diri dan kelompoknya.

\section{REFERENSI}

Ainissyifa, H. (2017). Pendidikan Karakter dalam Perspektif Pendidikan Islam. Jurnal Pendidikan UNIGA, 8(1), 1-26. Diambil dari https://journal.uniga.ac.id/index.php/JP/article/view/68

Asmani, J. M. (2011). Buku Panduan Internalisasi Pendidikan Karakter di Sekolah. Yogyakarta: Diva Press.

Haryati, Sri. (2017). Pendidikan Karakter Dalam Kurikulum 2013, Tersedia secara online di: http://lib.untidar.ac.id/wp-content/uploads/2017/01/Pendidikan-Karakterdalam-kurikulum.pdf [diakses di Bandung, Indonesia: 17 Maret 2017]

Hasan, Yetri \& Rijal Firdaos. (2017). Penguatan Pendidikan Karakter Berbasis Masyarakat pada SMPN di Kabupaten Tulang Bawang Provinsi Lampung. Al_tazkiyyah: Jurnal Pendidikan Islam, 8(2). Diambil dari http://ejournal.radenintan.ac.id/index.php/tadzkiyyah/article/view/2131

Kosim, Mohammad. (2011). Urgensi Pendidikan Karakter, KARSA: Journal of Social and Islamic Culture, 19(1), 84-92.

Lexy J, Moleong, (2004). Metodologi Penelitian Kualitatif. Bandung: PT. Remaja Rosdakarya.

Lickona, T. (1992). Educating for Character, How Our Schools Can Teach Respect and Reponsibility. New York: Bantam Books

Lukman hakim. (2017). Pengembangan Media Video Pembelajaran Untuk Mengembangkan Karakter Disiplin Siswa Di SDN Adisucipto 02. E-Jurnal Prodi Teknologi Pendidikan, Vol. VI Nomor 8 Tahun 2017

Marsianti, Andriana. (2014). Membangun Karakter Peduli Lingkungan di Sekolah (Upaya Penyelamatan Lingkungan Hidup), makalah belum terpublikasi, tanggal 17 Januari 2014.

Rozak, P. (2017). Indikator Tawadhu dalam Keseharian. Jurnal Ilmiah Madaniyah, 1(1). https://journal.stitpemalang.ac.id/index.php/madaniyah/article/view/69

Rusdi. (2013). Ajaibnya Tawadhu dan Istiqamah: Modal Sukses Luar Biasa. Yogyakarta: Sabil. Siswanto. (2013). Pendidikan Karakter Beerbasisi Niai-Nilai Relegius, Tadris: Jurnal Pendidikan Islam, 8(1). Diambil dari http:/ / ejournal.stainpamekasan.ac.id/index.php/tadris/article/view/385

Sumarlika. (2015). Fungsi Ekstrakurikuler Pada Kegiatan Kepramukaan Dalam Pembentukan Karakter Siswa Di SMP Negeri 4 Banyuasin III. Jurnal Bhineka Tunggal Ika. Volume 2. Nomor 2 November 2015

Sugiyono. (2008). Metode Penelitian Kuantitatif, Kualitatif, dan RED. Bandung: Alfabeta. Tabi'in, A. (2017). Menumbuhkan Sikap Peduli Pada Anak Melalui Interaksi Kegiatan Sosial. IJTIMAIYA, 1(1). Diambil dari http://journal.stainkudus.ac.id/index.php/Ijtimaia/article/view/3100 